Article

\title{
Evaluation of Marine Brown Algae and Sponges from Brazil as Anticoagulant and Antiplatelet Products
}

\author{
Laura de Andrade Moura ${ }^{1,2}$, Fredy Ortiz-Ramirez ${ }^{2}$, Diana Negrao Cavalcanti ${ }^{2}$, \\ Suzi Meneses Ribeiro ${ }^{3}$, Guilherme Muricy ${ }^{3}$, Valeria Laneuville Teixeira ${ }^{2}$ and \\ Andre Lopes Fuly ${ }^{1,2}$,*
}

1 Department of Molecular and Cellular Biology, Institute of Biology, Federal Fluminense University, Niteroi, 24020-141, RJ, Brazil; E-Mail: lauravivimel@gmail.com

2 Department of Marine Biology, Institute of Biology, Federal Fluminense University, Niteroi, 24020-141, RJ, Brazil; E-Mails: faortizr@ hotmail.com (F.O.-R.);

dn.cavalcanti@gmail.com (D.N.C.); valerialaneuville@gmail.com (V.L.T.)

3 Department of Invertebrates, Federal University of Rio de Janeiro, National Museum, 20940-040, RJ, Brazil; E-Mails: suzimr@yahoo.com.br (S.M.R.); muricy@mn.ufrj.br (G.M.)

* Author to whom correspondence should be addressed; E-Mail: andfuly@vm.uff.br; Tel.: +55-21-2629-2294; Fax: +55-21-2629-2376.

Received: 25 June 2011; in revised form: 26 July 2011 / Accepted: 4 August 2011 / Published: 10 August 2011

Abstract: The ischemic disorders, in which platelet aggregation and blood coagulation are
involved, represent a major cause of disability and death worldwide. The antithrombotic
therapy has unsatisfactory performance and may produce side effects. So, there is a need to
seek molecules with antithrombotic properties. Marine organisms produce substances with
different well defined ecological functions. Moreover, some of these molecules also exhibit
pharmacological properties such as antiviral, anticancer, antiophidic and anticoagulant
properties. The aim of this study was to evaluate, through in vitro tests, the effect of two
extracts of brown algae and ten marine sponges from Brazil on platelet aggregation and
blood coagulation. Our results revealed that most of the extracts were capable of inhibiting
platelet aggregation and clotting measured by plasma recalcification tests, prothrombin
time, activated partial thromboplastin time, and fibrinogenolytic activity. On the other
hand, five of ten species of sponges induced platelet aggregation. Thus, the marine
organisms studied here may have molecules with antithrombotic properties, presenting
biotechnological potential to antithrombotic therapy. Further chemical investigation should 
be conducted on the active species to discover useful molecules for the development of new drugs to treat clotting disorders.

Keywords: antithrombotic; bioprospecting; brown algae; marine sponges; natural products

\section{Introduction}

Hemostasis is a physiological process that involves platelet aggregation and blood coagulation. The coagulation system is divided into initiation and augmentation phases, and both lead to generation of thrombin, that is the pivotal enzyme responsible for formation of a fibrin net that prevents hemorrhage [1]. Platelets are equally important to form thrombus. After their activation by agonists (collagen, adenosine diphosphate (ADP) or thrombin), they contribute by amplifying the blood coagulation system [2]. If uncontrolled, coagulation may produce vascular disturbs, such as venous thromboembolism, cardiovascular disturbs or pulmonary embolism. These pathologies in fact, contribute to increases in mortality and morbidity in the world and have become a public health problem [3]. Actually, they represent the main cause of death, even more than cancer [4]. Therefore, safe and more efficient anticoagulants should be designed or discovered. In literature and in practice, a variety of drugs for managing thrombotic disorders have been used, including vitamin $\mathrm{K}$ antagonists, direct thrombin inhibitors, oral anticoagulants (apixaban, dabigatran and rivaroxaban), and recently a pentasaccharide. Heparin and warfarin are among the drugs associated with serious medication errors and are also considered as high-alert medications [5,6]. Antiplatelet drugs are also given to yield the greatest benefits, mainly to those patients at high thrombotic risk. These drugs may interfere with platelet adhesion, aggregation or activation, thus controlling the role of platelets in amplifying the thrombotic process [7]. Although these therapies have proven benefits, they have important limitations and may produce side effects, such as bleeding, thrombocytopenia, gastric disorders, narrow therapeutic index and window, drug or dietary interactions as well as sometimes requiring monitoring [3,8]. In fact, antithrombotic therapies may induce mild or even more severe symptoms. Because of this, researchers are looking for molecules with satisfactory antiplatelet and/or anticoagulation effects, but with no or low side effects [9]. Bioactive natural molecules are good candidates for such purposes [10-12]. As known, marine organisms produce a large amount of products, often so called secondary metabolites. They display ecological functions such as defense against predators, competitors and herbivores, prevention of biofouling [13,14] and some of them have been reported as having important pharmacological proprieties [15,16], such as antiviral [17-19], antilonomic [20], antiophidic [21], cytotoxic, antituberculosis [22], anti-inflammatory, antiangiogenic, antiadhesive [23] and anticoagulant [24]. Moreover, a large number of sulfated polysaccharides with antithrombotic effects have been isolated from marine algae [23,25-28] as well as from other natural sources; such as from lichens [29,30] or from Passiflora nitida leaves [31]. The inhibitory mechanism of action of these is still under investigation, but some speculate that molecules bind directly to thrombin and factor Xa, antithrombin and/or heparin cofactor II $[32,33]$. So, the purpose of this work was to investigate the effect of extracts from marine organisms from the Brazilian coast upon coagulation and platelet aggregation. 


\section{Results and Discussion}

\subsection{Effects on Platelet Aggregation}

The effect of extracts from algae or sponges on platelet aggregation and coagulation was studied; and it was shown that both marine organisms inhibited platelet aggregation or prevented plasma coagulation. Firstly, the effect of algae or sponges upon platelet aggregation was evaluated and they did not inhibit collagen-induced platelet aggregation on platelet rich plasma (PRP) (data not shown). On the other hand, the extracts of alga Dc-H (Figure 1A) or the sponges $\mathrm{Ch}$ and Pc (Figure 1B), inhibited the aggregation induced by ADP around 20\%. ADP and collagen bind to different receptors in platelet membrane and trigger platelet aggregation by different intracellular pathways [34,35]; and this fact may explain why algae or sponges inhibited only the ADP-induced aggregation, but not the collagen one. The extracts of algae or sponges did not induce aggregation on PRP (data not shown).

Figure 1. Effect of algae or sponges on platelet aggregation: Platelet rich plasma (PRP) was preincubated with dimethylsulfoxide (DMSO) $(0.9 \% \mathrm{v} / \mathrm{v}$, final concentration) extracts of algae (Panel A) or sponges (Panel B) for $2 \mathrm{~min}$ at $37^{\circ} \mathrm{C}$ under stirring. Then, adenosine diphosphate (ADP) $(15 \mu \mathrm{M})$ was added to induce platelet aggregation. One hundred percent of platelet aggregation was obtained with supramaximal concentrations of the agonist in presence of DMSO after 6 min. of reaction. Data are expressed as means \pm SEM of three individual experiments $(n=2)$. Asterisk used when $p<0.05$ compared to DMSO.
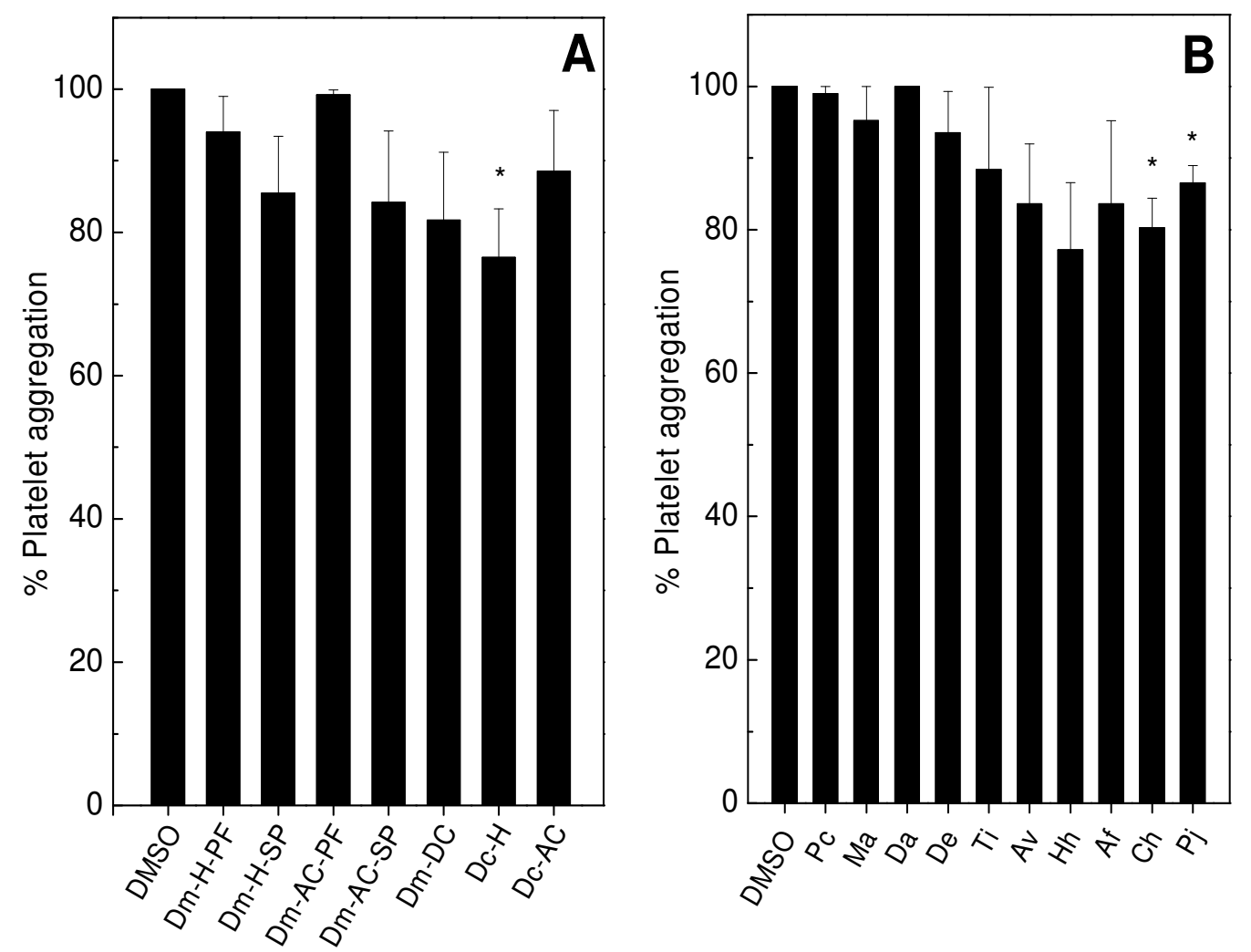

Then, the effect of algae or sponges upon aggregation of washed platelets (WP) was investigated (Figure 2). The extracts of alga Dm-H-PF and Dm-DC inhibited 30\% the aggregation induced by thrombin (Figure 2A) and 15\% induced by collagen (Figure 2B); while Dc-H inhibited aggregation 
around $85 \%$ (Figure 2A) and 60\% (Figure 2B). Dc-AC inhibited 20\% and 35\% aggregation induced by thrombin (Figure 2A) or collagen (Figure 2B), respectively. In fact, a more marked inhibitory effect on aggregation induced by thrombin or collagen could be observed for the extract of alga Dc- $\mathrm{H}$ (Figure 2A,B). Differences in the inhibitory profile may be explained by the fact that thrombin and collagen do not share the same receptors [36]. The experiments above were performed by incubating extracts of algae or sponges for 2 min with platelets. But when the algae Dc-H, Dm-H-PF, Dc-AC and $\mathrm{Dm}-\mathrm{DC}$ were incubated with WP for $10 \mathrm{~min}$, the inhibitory effect of them on platelet aggregation induced by collagen or thrombin was doubled (data not shown). The extracts of Dm-H-SP and Dm-Ac-PF did not inhibit aggregation of WP induced by thrombin (Figure 2A) or collagen (Figure 2B), even with 10 min incubation (data not shown). Four of ten sponges (De, Av, Hh and Af) inhibited aggregation of WP induced by thrombin (Figure 2C) or collagen (Figure 2D) after 2 min of incubation. Curiously, a $10 \%$ reduction on the inhibitory effect was observed when the sponges De, $\mathrm{Hh}$ or Af were incubated with platelets for $10 \mathrm{~min}$ (data not shown). The other two sponges (Pc, Av) did not inhibit aggregation either at $2 \mathrm{~min}$ or $10 \mathrm{~min}$ incubation. The extract of Pc did not interfere with platelet aggregation induced by both agonists (Figures 2C,D).

Figure 2. Effects of algae or sponges on washed platelet aggregation. The extracts of algae $(50 \mu \mathrm{g} / \mathrm{mL})$ or sponges $(100 \mu \mathrm{g} / \mathrm{mL})$ were preincubated with WP for 2 min at $37{ }^{\circ} \mathrm{C}$ under stirring, and then $0.4 \mathrm{U} / \mathrm{mL}$ thrombin (Panel A, C) or $16 \mu \mathrm{g} / \mathrm{mL}$ collagen (Panel B, D) was added to induce aggregation. One hundred percent of platelet aggregation was obtained with supramaximal concentrations of the agonists in presence of DMSO $(0.9 \% \mathrm{v} / \mathrm{v}$, final concentration) after $6 \mathrm{~min}$ of reaction. Data are expressed as means \pm SEM of three individual experiments $(n=2)$. Asterisk used when $p<0.05$ compared to DMSO.
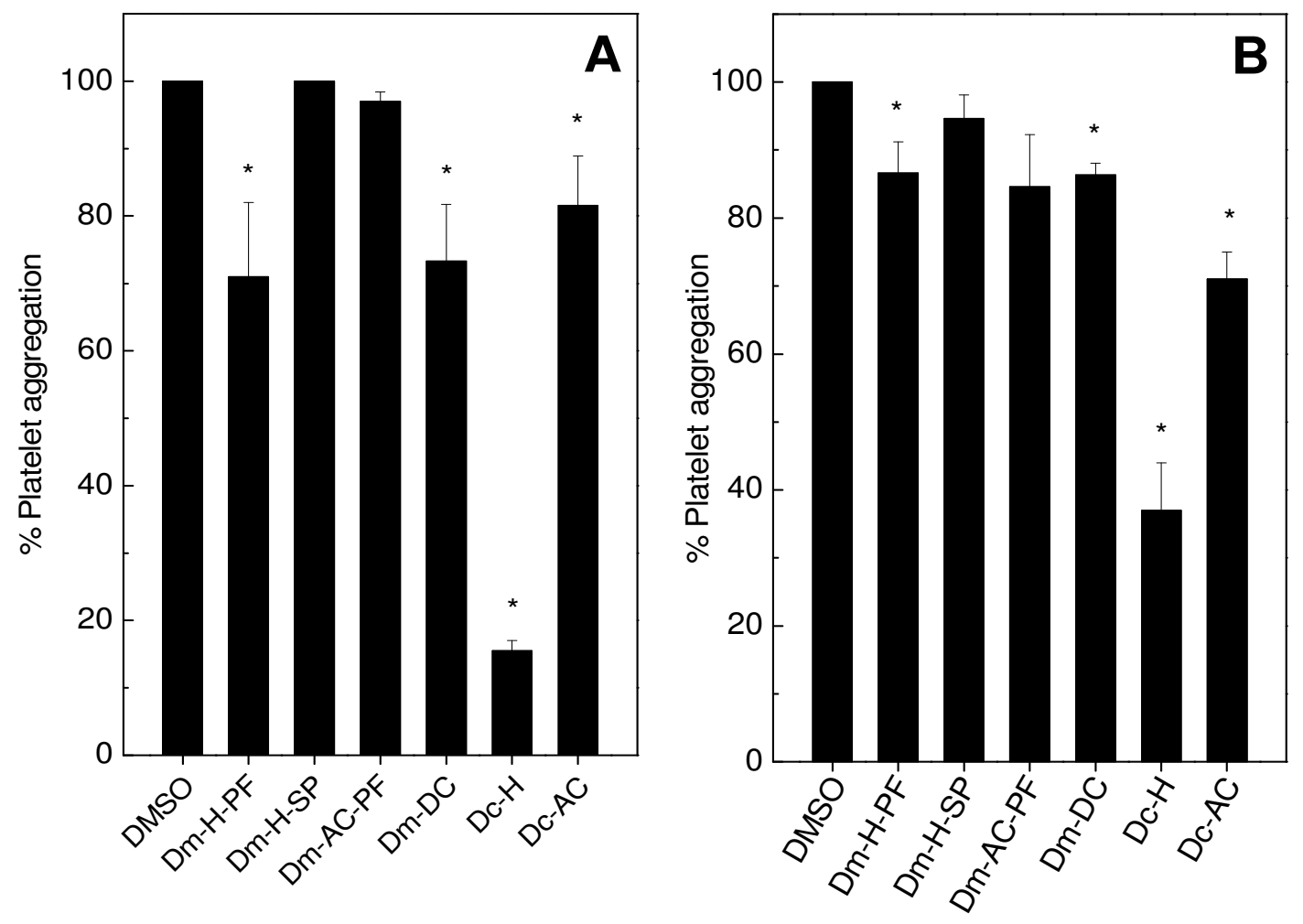
Figure 2. Cont.
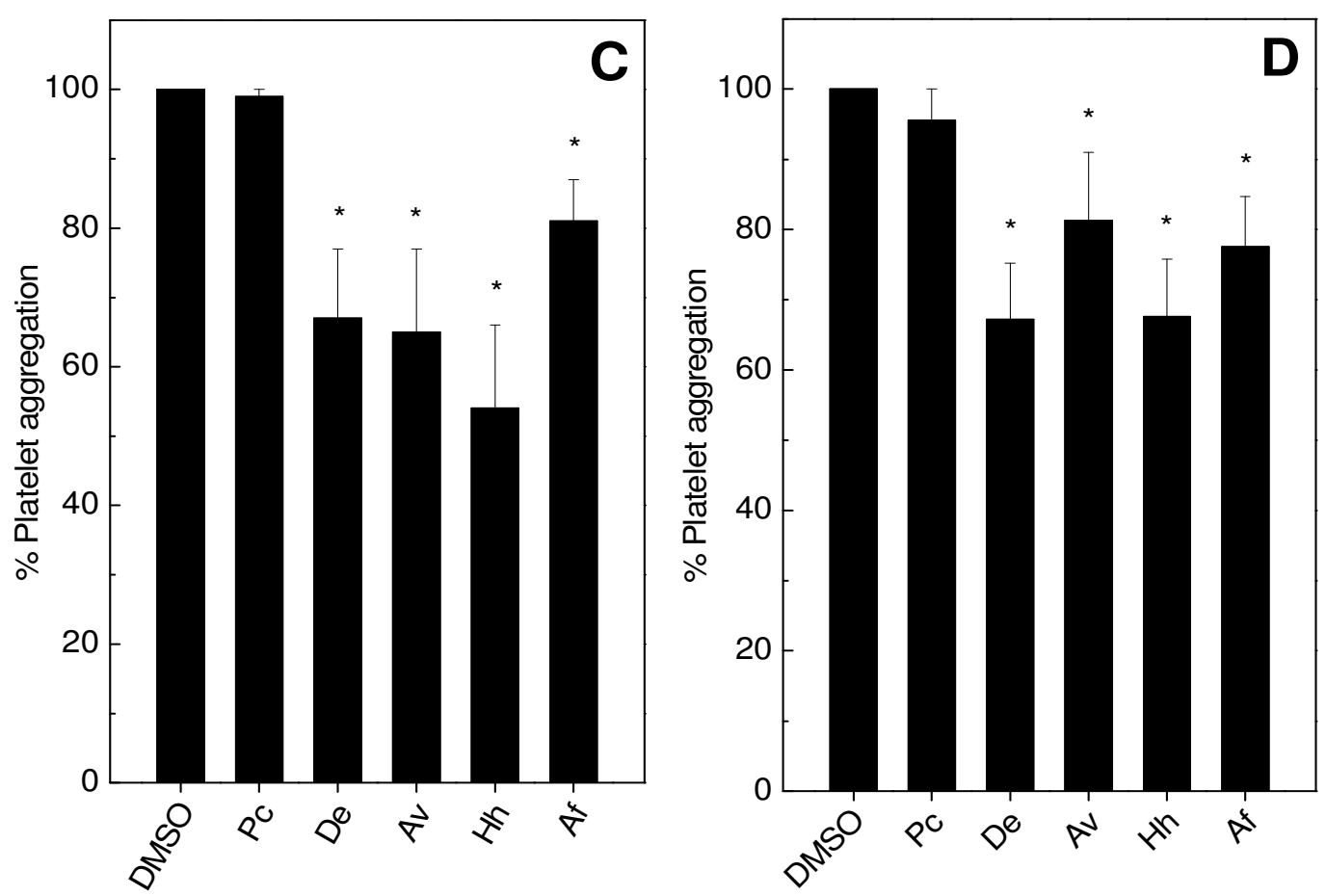

Regardless of the extract of sponge tested, a similar inhibitory pattern (from 50\% to $80 \%$ ) was observed for collagen or thrombin. As seen, most of algae and sponges did not inhibit platelet aggregation on PRP (Figure 1), in contrast to a pronounced inhibitory effect on WP (Figure 2). These results may suggest that blood plasma may somehow interfere in the inhibitory effect of extracts. Although the extracts inhibit platelet aggregation, they were not able to prevent shape-change which is at an early stage of platelet activation (data not shown). This dichotomy can be explained, since different receptors are involved in both processes. As known from literature, sugar rich-molecules can inhibit platelet aggregation [37-39]. However, none of the extracts from algae or sponges inhibited ristocetin-induced aggregation, except for alga Dc-H in which a $20 \%$ inhibition was observed (data not shown). So, the mechanism of action extracts seemed not to be the same as the sugars-enriched molecules. The inhibitory effect on aggregation of $\mathrm{Dc}-\mathrm{H}$, differed from other extracts of algae or sponges as it was concentration-dependent with an Inhibitory Concentration $\left(\mathrm{IC}_{50}\right)$ of $56 \mu \mathrm{g} / \mathrm{mL}$ for collagen and $47 \mu \mathrm{g} / \mathrm{mL}$ for thrombin (data not shown). Surprisingly, the extracts of $\mathrm{Ma}, \mathrm{Da}, \mathrm{Ti}, \mathrm{Ch}$ and $\mathrm{Pj}$ induced aggregation only when challenged with WP (data not shown), even though they have not induced aggregation on PRP. This result clearly shows the interference of plasma components in the extract-platelet interactions, since somehow molecules in plasma would bind to sponges' metabolites, preventing them from inducing aggregation; this was the case of PRP. The proaggregating mechanism of action is still under investigation.

\subsection{Effects on Coagulation}

A large number of bioactive molecules with anticoagulant activity have been described in marine organisms. These molecules are regularly produced from their primary or secondary metabolism, including polysaccharides [28] or diterpenes [8,21]. So, the influence of the extracts of algae (Table 1) 
or sponges (Table 2) on coagulation was evaluated using four in vitro methods: (1) the recalcification time (RT); (2) prothrombin time (PT); (3) activated partial thromboplastin time (aPTT); and (4) fibrinogen clotting (FC). None of the extracts from algae or sponges exerted a pro-coagulant activity (data not shown). However, most of them inhibited coagulation, but with different potencies. The extracts of algae did not delay coagulation on the recalcification test at 5 or $10 \mathrm{~min}$ of incubation, but Dm-AC-PF and Dc-AC did delay PT and aPTT times, respectively (Table 1). The in vitro anticoagulant effect of such algae suggests that the former may have molecules that act in the extrinsic pathway (initiation) of the coagulation system, while the latter acts in the intrinsic one (augmentation). The higher anticoagulant effect of algae was observed upon fibrinogen clotting elicited by thrombin (Table 1). It is well known that thrombin generates fibrin through cleavage fibrinogen and induces platelet aggregation, and these two effects are mediated by two distinct sites, a catalytic site and a pharmacological one. So, we may speculate that algae extracts could also inhibit the enzymatic activity of thrombin. To test it, we evaluated the ability of algae to inhibit hydrolysis of S-2238 that is a specific substrate for thrombin. However, none of the extracts prevented hydrolysis by thrombin (data not shown); suggesting that the anticlotting effect of algae upon fibrinogen might not be associated with thrombin activity or that algae do not bind to the catalytic site of thrombin.

Table 1. Effect of algae extracts on clotting times. For RT, the extracts of algae $(50 \mu \mathrm{g} / \mathrm{mL})$ were preincubated with plasma and then $\mathrm{CaCl}_{2}$ was added to trigger coagulation. For PT, extracts $(100 \mu \mathrm{g} / \mathrm{mL})$ were incubated with plasma and then thromboplastin was added to induce coagulation. For aPTT, extracts $(100 \mu \mathrm{L} / \mathrm{mL})$ were incubated with plasma plus cephalin then $\mathrm{CaCl} 2$ was added to trigger coagulation. For FC, extracts $(100 \mu \mathrm{g} / \mathrm{mL})$ were incubated with fibrinogen and then thrombin $(1 \mathrm{U} / \mathrm{mL})$ was added to induce coagulation. Results are expressed as means \pm SEM of two individual experiments $(n=4)$. Asterisk used when $p<0.05$ compared to $\mathrm{NaCl}$ or DMSO $(1 \% \mathrm{v} / \mathrm{v})$. See Table 3 for species names.

\begin{tabular}{ccccc}
\hline \multirow{2}{*}{ Samples } & \multicolumn{4}{c}{ Clotting times (s) } \\
\cline { 2 - 5 } & RT & PT & aPTT & FC \\
\hline NaCl & $122.8 \pm 16$ & $21.7 \pm 0.3$ & $32.1 \pm 1.2$ & $26.4 \pm 0.5$ \\
DMSO & $149.7 \pm 3.3$ & $25.6 \pm 0.2$ & $38.8 \pm 0.8$ & $34.1 \pm 1.4$ \\
Dm-H-PF & $158.3 \pm 11$ & $24.5 \pm 0.2$ & $38.7 \pm 2.0$ & $46.8 \pm 1.3 *$ \\
Dm-H-SP & $156.2 \pm 8.3$ & $25.1 \pm 0.4$ & $39.3 \pm 1.3$ & $47.3 \pm 1.6 *$ \\
Dm-AC-PF & $172.3 \pm 13$ & $29.9 \pm 0.6 *$ & $40.5 \pm 1.1$ & $86.4 \pm 2.6 *$ \\
Dm-AC-SP & $155.6 \pm 3.2$ & $24.7 \pm 1.0$ & $39.1 \pm 0.7$ & $65.3 \pm 3.5 *$ \\
Dm-DC & $171.6 \pm 14$ & $23.3 \pm 0.2$ & $40.2 \pm 0.5$ & $66.7 \pm 0.8 *$ \\
Dc-H & $177.4 \pm 13$ & $27.3 \pm 0.2$ & $38.7 \pm 2.4$ & $42.7 \pm 0.9 *$ \\
Dc-AC & $166.1 \pm 4.1$ & $28.9 \pm 0.2$ & $46.1 \pm 2.5 *$ & $78.4 \pm 11 *$ \\
\hline
\end{tabular}

Moreover, the extracts of sponges also inhibited clotting (Table 2). It seems that sponges were more effective than algae, since they inhibited coagulation in the four methods (Table 2). The extracts of $\mathrm{Ti}$, $\mathrm{Ch}$ and $\mathrm{Pj}$ doubled coagulation time in each of the four methods; but, Ti was the most effective. Only the extracts of sponges $\mathrm{Da}$, De and $\mathrm{Hh}$ did not delay coagulation in the recalcification test (Table 2). As in the algae tests, the extracts of sponges did not inhibit hydrolysis of S-2238 (data not shown). 
Table 2. Effect of the extracted sponges on clotting time. For RT, the extracts $(50 \mu \mathrm{g} / \mathrm{mL})$ were preincubated with plasma and then $\mathrm{CaCl}_{2}$ was added to trigger coagulation. For PT, extracts $(100 \mu \mathrm{g} / \mathrm{mL})$ were incubated with plasma and then thromboplastin was added to induce coagulation. For aPTT, the extracts $(100 \mu \mathrm{L} / \mathrm{mL})$ were incubated with plasma plus cephalin then $\mathrm{CaCl}_{2}$ was added to trigger coagulation. For $\mathrm{FC}$, the extracts $(100 \mu \mathrm{g} / \mathrm{mL})$ were incubated with fibrinogen and then thrombin $(1.0 \mathrm{U} / \mathrm{mL})$ was added to induce coagulation. Results are expressed as means \pm SEM of two individual experiments $(n=4)$. Asterisk used when $p<0.05$ compared to $\mathrm{NaCl}$ or DMSO $(1 \% \mathrm{v} / \mathrm{v})$. See Table 4 for species names.

\begin{tabular}{ccccc}
\hline \multirow{2}{*}{ Samples } & \multicolumn{4}{c}{ Clotting times (s) } \\
\cline { 2 - 5 } & RT & PT & aPTT & FC \\
\hline $\mathrm{NaCl}$ & $124.3 \pm 7.2$ & $21.7 \pm 0.3$ & $32.1 \pm 1.2$ & $25.2 \pm 0.1$ \\
$\mathrm{DMSO}$ & $160.6 \pm 11.5$ & $22.7 \pm 0.2$ & $34.8 \pm 1.3$ & $34.4 \pm 0.4$ \\
$\mathrm{Pc}$ & $203.5 \pm 4.7 *$ & $27.4 \pm 1.0 *$ & $48.5 \pm 1.4 *$ & $86.6 \pm 5.8 *$ \\
$\mathrm{Ma}$ & $227.0 \pm 8.0 *$ & $27.1 \pm 0.7 *$ & $54.8 \pm 2.0 *$ & $99.8 \pm 9.6 *$ \\
$\mathrm{Da}$ & $210.6 \pm 17.1$ & $27.9 \pm 1.2 *$ & $52.3 \pm 1.7 *$ & $88.9 \pm 6.9 *$ \\
$\mathrm{De}$ & $197.2 \pm 10.6$ & $26.3 \pm 0.4 *$ & $54.1 \pm 1.2 *$ & $101.6 \pm 6.0 *$ \\
$\mathrm{Ti}$ & $246.0 \pm 9.3 *$ & $27.3 \pm 0.8 *$ & $64.2 \pm 1.7 *$ & $176.2 \pm 4.7 *$ \\
$\mathrm{Av}$ & $239.3 \pm 14.8 *$ & $27.1 \pm 0.6 *$ & $58.0 \pm 1.6 *$ & $94.4 \pm 5.4 *$ \\
$\mathrm{Hh}$ & $185.6 \pm 10.1$ & $23.9 \pm 0.6$ & $40.6 \pm 1.1 *$ & $76.6 \pm 3.1 *$ \\
$\mathrm{Af}$ & $234.6 \pm 13.6 *$ & $25.7 \pm 0.5 *$ & $45.2 \pm 2.2 *$ & $75.9 \pm 5.4 *$ \\
$\mathrm{Ch}$ & $296.3 \pm 29.0 *$ & $27.5 \pm 0.4 *$ & $53.2 \pm 2.8 *$ & $92.6 \pm 8.1 *$ \\
$\mathrm{Pj}$ & $278.6 \pm 6.5 *$ & $26.3 \pm 0.5 *$ & $52.2 \pm 1.0 *$ & $107.1 \pm 5.0 *$ \\
\hline
\end{tabular}

Table 3. Extracts of algae studied with their solvent, collection site, voucher specimen and code.

\begin{tabular}{c|c|c|c|c}
\hline Algae & Solvent & Collection Site & Voucher & Code \\
\hline $\begin{array}{c}\text { Dictyota } \\
\text { menstrualis }\end{array}$ & Ethyl Acetate & $\begin{array}{c}\text { Arquipélago de São } \\
\text { Pedro e São Paulo, RN } \\
\left(00^{\circ} 55^{\prime} \mathrm{N}-29^{\circ} 21^{\prime} \mathrm{W}\right)\end{array}$ & 11006 & Dm-AC-SP \\
\hline $\begin{array}{c}\text { Dictyota } \\
\text { menstrualis }\end{array}$ & Ethyl Acetate & $\begin{array}{c}\text { Praia do Forno } \\
\text { Armação de Búzios, RJ } \\
\left(22^{\circ} 45^{\prime} \mathrm{S}-41^{\circ} 52^{\prime} \mathrm{W}\right)\end{array}$ & 84815 & Dm-AC-PF \\
\hline $\begin{array}{c}\text { Dictyota } \\
\text { menstrualis }\end{array}$ & Hexane & $\begin{array}{c}\text { Arquipélago de São } \\
\text { Pedro e São Paulo, RN } \\
\left(00^{\circ} 55^{\prime} \mathrm{N}-29^{\circ} 21^{\prime} \mathrm{W}\right)\end{array}$ & 11006 & Dm-H-SP \\
\hline $\begin{array}{c}\text { Dictyota } \\
\text { menstrualis }\end{array}$ & Hexane & $\begin{array}{c}\text { Praia do Forno } \\
\text { Armação de Búzios, RJ } \\
\left(22^{\circ} 45^{\prime} \mathrm{S}-41^{\circ} 52^{\prime} \mathrm{W}\right)\end{array}$ & 84815 & Dm-H-PF \\
\hline $\begin{array}{c}\text { Dictyota } \\
\text { menstrualis }\end{array}$ & Dichloromethane & $\begin{array}{c}\text { Praia Rasa } \\
\text { Armação de Búzios, RJ } \\
\left(22^{\circ} 45^{\prime} \mathrm{S}-41^{\circ} 52^{\prime} \mathrm{W}\right)\end{array}$ & 10017 & Dm-DC \\
\hline $\begin{array}{c}\text { Dictyota } \\
\text { ciliolata }\end{array}$ & Hexane & $\begin{array}{c}\text { Praia Vermelha } \\
\left(23^{\circ} 00^{\prime} \mathrm{S}-44^{\circ} 19^{\prime} \mathrm{W}\right)\end{array}$ & 10415 & Dc-H \\
\hline $\begin{array}{c}\text { Praia Vermelha } \\
\text { ciliolata }\end{array}$ & Ethyl Acetate & $\begin{array}{c}\text { Angra dos Reis, RJ } \\
\left(23^{\circ} 00^{\prime} \mathrm{S}-44^{\circ} 19^{\prime} \mathrm{W}\right)\end{array}$ & 10415 & Dc-AC \\
\hline
\end{tabular}


Table 4. Extracts of sponges studied with their solvent, collection site, voucher specimen and code.

\begin{tabular}{|c|c|c|c|c|}
\hline Sponge & Solvent & Collection Site & Voucher & Code \\
\hline $\begin{array}{l}\text { Petromica } \\
\text { citrina }\end{array}$ & Dichloromethane & $\begin{array}{c}\text { Arquipélago das Cagarras } \\
\text { Rio de Janeiro, RJ } \\
\left(23^{\circ} 01^{\prime} \mathrm{S}-43^{\circ} 13^{\prime} \mathrm{W}\right)\end{array}$ & 14537 & $\mathrm{Pc}$ \\
\hline $\begin{array}{c}\text { Mycale } \\
\text { angulosa }\end{array}$ & Acetone & $\begin{array}{c}\text { Praia da Baleia } \\
\text { Angra dos Reis, RJ } \\
\left(23^{\circ} 01^{\prime} \mathrm{S}-44^{\circ} 14^{\prime} \mathrm{W}\right)\end{array}$ & 14529 & Ma \\
\hline Chondrosia sp. & Acetone & $\begin{array}{c}\text { Praia da Baleia } \\
\text { Angra dos Reis, RJ } \\
\left(23^{\circ} 01^{\prime} \mathrm{S}-44^{\circ} 14^{\prime} \mathrm{W}\right) \\
\end{array}$ & 14551 & $\mathrm{Ch}$ \\
\hline $\begin{array}{l}\text { Dysidea } \\
\text { etherea }\end{array}$ & Acetone & $\begin{array}{c}\text { Praia da Baleia } \\
\text { Angra dos Reis, RJ } \\
\left(23^{\circ} 01^{\prime} \mathrm{S}-44^{\circ} 14^{\prime} \mathrm{W}\right) \\
\end{array}$ & 14525 & $\mathrm{De}$ \\
\hline $\begin{array}{c}\text { Desmapsamma } \\
\text { anchorata }\end{array}$ & Acetone & $\begin{array}{c}\text { Ilha do Bonfim } \\
\text { Angra dos Reis, RJ } \\
\left(23^{\circ} 01^{\prime} \mathrm{S}-44^{\circ} 19^{\prime} \mathrm{W}\right) \\
\end{array}$ & 14520 & $\mathrm{Da}$ \\
\hline $\begin{array}{c}\text { Amphimedon } \\
\text { viridis }\end{array}$ & Acetone & $\begin{array}{c}\text { Ilha do Bonfim. } \\
\text { Angra dos Reis, RJ } \\
\left(23^{\circ} 01^{\prime} \mathrm{S}-44^{\circ} 19^{\prime} \mathrm{W}\right) \\
\end{array}$ & 14517 & Av \\
\hline Tedania ignis & Acetone & $\begin{array}{c}\text { Praia de Tarituba } \\
\text { Paraty, RJ } \\
\left(23^{\circ} 02^{\prime} \mathrm{S}-44^{\circ} 35^{\prime} \mathrm{W}\right) \\
\end{array}$ & 14522 & $\mathrm{Ti}$ \\
\hline $\begin{array}{l}\text { Hymeniacidon } \\
\text { heliophila }\end{array}$ & Acetone & $\begin{array}{c}\text { Praia de Itaipu } \\
\text { Niterói, RJ } \\
\left(22^{\circ} 58^{\prime} \mathrm{S}-43^{\circ} 02^{\prime} \mathrm{W}\right) \\
\end{array}$ & 14528 & $\mathrm{Hh}$ \\
\hline $\begin{array}{l}\text { Aplysina } \\
\text { fulva }\end{array}$ & Acetone & $\begin{array}{c}\text { Praia do Forno } \\
\text { Arraial do Cabo, RJ } \\
\left(22^{\circ} 57^{\prime} \mathrm{S}-42^{\circ} 00^{\prime} \mathrm{W}\right) \\
\end{array}$ & 13554 & Af \\
\hline $\begin{array}{l}\text { Polymastia } \\
\text { janeirensis }\end{array}$ & Acetone & $\begin{array}{c}\text { Praia do Forno } \\
\text { Arraial do Cabo, RJ } \\
\left(22^{\circ} 57^{\prime} \mathrm{S}-42^{\circ} 00^{\prime} \mathrm{W}\right) \\
\end{array}$ & 14512 & $\mathrm{Pj}$ \\
\hline
\end{tabular}

Concerning the extracts of algae, the collection site and the type of extract may have influenced the results, mainly because of the geographical variation of each species and the chemical composition of extracts. It is worthwhile to mention that the polarity of solvents may also influence the potency of some pharmacological effects, since different molecules can be extracted [40]. The extracts evaluated in this work contain nonpolar molecules, such as diterpenes, fatty acids or sterols. As can be seen, the extracts of D. menstrualis prepared in ethyl acetate from Búzios (Dm-AC-PF) and D. ciliolata in hexane from Angra dos Reis (Dc-H) presented the most expressive anticoagulant activity. The extract of Ti had the best anticoagulant effect among sponges. 


\section{Experimental Section}

\subsection{Material}

Collagen (Type I), ristocetin and adenosine diphosphate (ADP) were purchased from Chrono Log Corporation, dimethylsulfoxide (DMSO) and human thrombin from Merck. Chromogenic substrate, H-D-Phe-pipecolyl-Arg-pNA.2HCl (S-2238) came from Chromogenix. All the others reagents were of the best grade available.

\subsection{Marine Organisms}

The air-dried algae (Table 3) and the frozen-dried sponge (Table 4) were collected in regions of Brazilian coast by free or scuba diving and extracted three times with appropriate solvent at room temperature $\left(25^{\circ} \mathrm{C}\right)$ for $24 \mathrm{~h}$ (Tables 3 and 4$)$. After filtration, the solvent was evaporated under reduced pressure, yielding a crude residue. An aliquot of each extract was weighted, aliquoted and frozen. The extracts were dissolved in DMSO in order to perform the biological assays, and right after assays, extracts were stored at $4{ }^{\circ} \mathrm{C}$. A voucher specimen of each sponge has been deposited at National Museum of the Federal University of Rio de Janeiro (MN-UFRJ), Rio de Janeiro, Brazil. Each species of algae was deposited at the Herbarium of State University of Rio de Janeiro (UERJ), RJ, Brazil and authenticated by Dr. Joel Campos de Paula (UNIRIO). The experimental procedures employed here removed sugar, lipids and proteins, and extracted less polar components and nonpolar ones, as diterpenes, fatty acids and sterols.

\subsection{Platelet Aggregation Assays}

The procedure described by [41] was employed with some modifications. Platelet aggregation was measured turbidimetrically in an Aggregometer (Chrono Log model 490 2D, Havertown, USA) using Platelet-Rich-Plasma (PRP) or Washed-Platelets (WP). PRP (collected in citrate $0.38 \% \mathrm{w} / \mathrm{v}$ ) and WP (collected in $5 \mathrm{mM}$ EDTA) were obtained from whole blood of healthy volunteer donators and centrifuged at $380 \times \mathrm{g}$ for $12 \mathrm{~min}$ at room temperature. The extracts of either algae or sponges were incubated with $250 \mu \mathrm{L}$ PRP or WP for $2 \mathrm{~min}$ at $37{ }^{\circ} \mathrm{C}$ under stirring, and then platelet aggregation was triggered by adding platelet agonists (collagen, ADP, ristocentin or thrombin). Assays were performed at $37{ }^{\circ} \mathrm{C}$ in siliconized glass cuvettes with a total volume of $300 \mu \mathrm{L}$. Control experiments were performed using platelet agonists in the presence or in the absence of DMSO $(0.9 \% \mathrm{v} / \mathrm{v}$, final concentration). One hundred percent (100\%) of aggregation was obtained with a supra maximal concentration of agonists $6 \mathrm{~min}$ after the addition of agonist, whilst $0 \%$ of aggregation was the light transmittance of PRP or WP alone (base line). The Inhibitory Concentration $\left(\mathrm{IC}_{50}\right)$ was determined as the amount of extract $(\mu \mathrm{g} / \mathrm{mL})$ able to inhibit $50 \%$ of platelet aggregation induced by agonists.

\subsection{Clotting Assays}

Four in vitro clotting assays were performed using a Multichannel Coagulometer (Amelung, model $\mathrm{KC} 4 \mathrm{~A}$ ), as listed below. 
Recalcification Time (RT): The extracts of algae or sponges were incubated with $200 \mu \mathrm{L}$ of a pool of normal human plasma (collected in citrate $3.8 \% \mathrm{v} / \mathrm{v}$ ) for $10 \mathrm{~min}$ at $37{ }^{\circ} \mathrm{C}$. Then, $\mathrm{CaCl}_{2}(12.5 \mathrm{mM}$ final concentration) was added to the mixture and clotting time recorded.

Prothrombin Time (PT) and Activated Partial Thromboplastin Time (aPTT) tests: Both assays were performed according to the manufacturer instructions (Soluplastin and aPTTest elagic acid, Wiener lab). For PT assays, extracts were incubated with $50 \mu \mathrm{L}$ of human plasma during 5 min at $37{ }^{\circ} \mathrm{C}$ and then $100 \mu \mathrm{L}$ of pre-warmed thromboplastin with calcium were added to the mixture to start clotting. For aPTT assay, extracts were mixed with $100 \mu \mathrm{L}$ of human plasma and $100 \mu \mathrm{L}$ of aPTT reagent cephalin plus kaolin for 5 min at $37{ }^{\circ} \mathrm{C}$. The reaction was started by the addition of $\mathrm{CaCl}_{2}(12.5 \mathrm{mM}$, final concentration).

Fibrinogen clotting (FC): The extracts of algae and sponges were incubated for $10 \mathrm{~min}$ at $37{ }^{\circ} \mathrm{C}$ with $200 \mu \mathrm{L}$ of commercial fibrinogen $(2 \mathrm{mg} / \mathrm{mL}$, final concentration). After this, clotting was triggered by adding thrombin $(1.0 \mathrm{U} / \mathrm{mL})$.

\subsection{Hydrolytic Activity upon Chromogenic Assay}

The hydrolysis of the chromogenic substrate S-2238 (used for thrombin-like enzymes) was monitored by using a Thermomax Microplate reader (Molecular Devices, Menlo Park, CA, USA). The extracts of algae or sponges were incubated for $10 \mathrm{~min}$ at $37{ }^{\circ} \mathrm{C}$, and then reaction was triggered by adding S-2238 (0.1 mM, final concentration). The reaction was monitored at $\mathrm{A}_{405 \mathrm{~nm}}$ during $20 \mathrm{~min}$ at $37{ }^{\circ} \mathrm{C}$. Positive control experiments were performing by adding thrombin $(1.0 \mathrm{U} / \mathrm{mL})$, instead of marine organisms.

\subsection{Statistical Analyses}

The results were expressed as means \pm standard error (SEM) obtained with an indicated number of experiments performed. The statistical significance of differences among experimental groups and control groups were evaluated using Student $t$ test with $p$ value $<0.05$.

\section{Conclusions}

In this work, we screened extracts from Brazilian algae and sponges having the capacity to interfere with platelet aggregation and coagulation and, thereby, observed that some extracts inhibited coagulation and platelet aggregation. Further chemical work should be done to identify which specific bioactive principle in algae or sponges is responsible for the anticoagulant effect and also to understand the structure-function relationship involved in such phenomena. Moreover, this work also shows the importance of bioprospecting studies with the rich marine biodiversity along the Brazilian coast, looking for natural compounds with pharmacological properties or biotechnological potential which could be used in the development of new clinical drugs. Up to now, it is very difficult to address advantages of algae or sponges over existing anticoagulant therapies or their role in thrombotic processes. However, we can infer some favorable points that are worth further studying and looking for molecules from marine organisms with an anticoagulant effect: (1) actually, there is more interest in developing therapeutic agents from a non-mammalian source in order to diminish side effects 
(such as hemorrhage), risk of contamination with foreign bodies or pathogenic substances; (2) marine products could also be useful to help to design new structure-based anticoagulant drugs.

\section{Acknowledgements}

Research was supported by IFS (Grant F/4571-1), FAPERJ, CNPq, CAPES, UFF/PROPPi. VLT and ALF thank CNPq for fellowship support.

\section{References}

1. Esmon, C.T. Regulation of blood coagulation. Biochim. Biophys. Acta 2000, 1477, 349-360.

2. Andrews, R.K.; Berndt, M.C. Platelet physiology and thrombosis. Thromb. Res. 2004, 114, 447-453.

3. Agnelli, G. Current issues in Anticoagulation. Pathophysiol. Haemost. Thromb. 2005, 34, $2-9$.

4. Sattari, M.; Lowenthal, D.T. Novel oral anticoagulant in development: Dabigatran, Rivaroxaban and Apixaban. Am. J. Ther. 2011, 18, 332-338.

5. Reis, A.M.M.; Marques, T.C.; Opitz, S.P.; Silva, A.E.B.C.; Gimenes, F.R.E.; Teixeira, T.C.A.; Lima, R.E.F.; Cassiani, S.H.B. Errors in medicine administration-profile of medicines: Knowing and preventing. Acta Paul. Enferm. 2010, 23, 181-186.

6. Pirmohamed, M.; James, S.; Meakin, S.; Green, C.; Scott, A.K.; Walley, T.J.; Farrar, K.; Park, B.K.; Breckenridge, A.M. Adverse drug reactions as cause of admission to hospital: Prospective analysis of 18,820 patients. Br. Med. J. 2004, 329, 15-19.

7. Lopes, R.D. Antiplatelet agents in cardiovascular disease. J. Thromb. Thrombol. 2011, 31, 306-309.

8. Moura, L.A.; Bianco, E.M.; Pereira, R.C.; Teixeira, V.L.; Fuly, A.L. Anticoagulation and antiplatelet effects of a dolastane diterpene isolated from the marine brown alga Canistrocarpus cervicornis. J. Thromb. Thrombol. 2001, 31, 235-240.

9. Nutescu, E.A.; Shapiro, N.L.; Chevalier, A.; Amin, A.N. A pharmacological overview of current and emerging anticoagulants. Clev. Clin. J. Med. 2005, 72, 2-6.

10. Costello, M.J.; Coll, M.; Danovaro, R.; Halpin, P.; Ojaveer, H.; Milolasvich, P. A Census of Marine Biodiversity Knowledge, Resources, and Future Challenges. PLoS One 2010, 5, 12110.

11. Usami, Y. Recent synthetic studies leading to structural revisions of marine natural products. Mar. Drugs 2009, 7, 314-330.

12. Güven, K.C.; Percot, A.; Sezik, E. Alkaloids in Marine Algae. Mar. Drugs 2010, 8, 269-284.

13. Clavico, E.E.G.; Muricy, G.; Gama, B.A.P.; Batista, D.; Ventura, C.R.R.; Pereira, R.C. Ecological roles of natural products from the marine sponge Geodia corticostylifera. Mar. Biol. 2006, 148, 479-488.

14. Teixeira, V.L. Produtos Naturais Marinhos. In Biologia Marinha, 2nd ed.; Pereira, R.C., Soares-Gomes, A., Eds.; Editora Interciência: Rio de Janeiro, Brazil, 2002; pp. 443-472.

15. Mayer, A.M.S.; Rodrígez, A.D.; Berlink, R.G.S.; Hamann, M.T. Marine pharmacology in 2003-4: Marine compounds with anthelmintic, antibacterial, anticoagulant, antifungal, anti-inflammatory, antimalarial, antiplatelet, antiprotozoal, antituberculosis, and antiviral activities; affecting the cardiovascular, immune and nervous systems, and other miscellaneous mechanisms of action. Comp. Biochem. Physiol. 2007, 145, 553-581. 
16. Molinski, T.F.; Dalisay, D.S.; Lievens, S.L.; Saludes, J.P. Drug development from marine natural products. Nat. Rev. Drug Discov. 2009, 8, 69-85.

17. Cirne-Santos, C.C.; Teixeira, V.L.; Castello-Branco, L.R.; Frugulhetti, I.C.P.P.; Bou-Habib, D.C. Inhibition of HIV-1 replication ih human primary cells by a dolabellane diterpene isolated from the marine algae Dictyota pfafii. Planta Med. 2006, 72, 295-299.

18. Soares, A.R.; Abrantes, J.L.; Souza, T.M.L.; Leite Fontes, C.F.; Pereira, R.C.; Frugulhetti, I.C.P.P.; Teixeira, V.L. In vitro antiviral effect of meroditerpenes isolated from the brazilian seawwed Stypopodium zonale (Dictyotales). Planta Med. 2007, 73, 1-4.

19. Souza, T.M.; Abrantes, J.L.; Epifanio, R.A.; Leite Fontes, C.F.; Frugulhetti, I.C.P.P. The alkaloid 4-methylaaptamine isolated from the sponge Aaptos aaptos impairs Herpes simplex virus type 1 penetration and immediate-early protein synthesis. Planta Med. 2007, 73, 200-205.

20. Domingos, T.F.S.; Carvalho, C.; Moura, L.A.; Teixeira, V.L.; Pereira, R.C.; Bianco, E.M.; Ferreira, W.J.; Ramos, C.J.B.; de Miranda, A.L.P.; Melo, P.A.; et al. Antilonomic effects of brazilian brown seaweeds extracts. Nat. Prod. Commun. 2009, 4, 1075-1078.

21. Moura, L.A.; Sanchez, E.F.; Bianco, E.M.; Pereira, R.C.; Teixeira, V.L.; Fuly, A.L. Antiophidian properties of a dolastane diterpene isolated from the marine brown alga Canistrocarpus cervicornis. Biomed. Pharmacother. 2010, doi:10.1016/j.biopha.2010.09.023.

22. Azevedo, L.G.; Muccillo-Baisch, A.L.; Figueira, D.M.V.B.; Boyle, R.T.; Ramos, D.F.; Soares, A.D.; Lerner, C.; Silva, P.A.; Trindade, G.S. Comparative cytotoxic and anti-tuberculosis activity of Aplysina caissara marine sponge crude extracts. Comp. Biochem. Physiol. 2008, 147, $36-42$.

23. Cumashi, A.; Ushakova, N.A.; Preobrazhenskaya, M.E.; D’Incecco, A.; Piccoli, A.; Totani, L.; Tirani, N.; Morozevich, G.E.; Berman, A.E.; Bilan, M.I.; et al. A comparative study of the anti-inflammatory, anticoagulant, antiangiogenic, and antiadhesive activities of nine different fucoidans from brown seaweeds. Glycobiology 2007, 17, 541-552.

24. Albuquerque, I.R.L.; Queiroz, K.C.S.; Alves, L.G.; Santos, E.A.; Leite, E.L.; Rocha, H.A.O. Heterofucans from Dictyota menstrualis have anticoagulant activity. Braz. J. Med. Biol. Res. 2004, 37, 167-171.

25. Wijesekara, I.; Pangestuti, R.; Kim, S. Biological activities and potential health benefits of sulfated polysaccharides derived from marine algae. Carbohydr. Polym. 2011, 84, 14-21.

26. Matsubara, K. Recent advances in marine algal anticoagulants. Curr. Med. Chem. Cardiovasc. Hematol. Agents 2004, 2, 13-19.

27. Mourão, P.A.S. Use of Sulfated fucans as anticoagulant and antithrombotic agents: Future Perspectives. Curr. Pharm. Des. 2004, 10, 967-981.

28. Camara, R.B.G.; Costa, L.S.; Fidelis, G.P.; Nobre, L.T.D.B.; Dantas-Santo, N.; Cordeiro, S.L.; Costa, M.S.S.P.; Alves, L.G.; Rocha, H.A.O. Heterofucans from the brown seaweed Canistrocarpus cervicornis with anticoagulant and antioxidant activities. Mar. Drugs 2011, 9 , 124-138.

29. Lee, K.; Kim, M. Antiplatelet and antithrombotic activities of Methanol Extract of Usnea longissima. Phytother. Res. 2005, 19, 1061-1064.

30. Kim, M.; Lee, K. Antithrombotic activity of methanolic extract of Umbilicaria esculenta. J. Ethnopharmacol. 2006, 105, 342-345. 
31. Carvalho, M.J.; Pedrosa, T.N.; Guilhon-Simplicio, F.; Nunez, C.V.; Ohana, D.T.; Pereira, M.M.; Lima, E.S. Pharmacognostic study and in vitro activity on blood coagulation and platelet aggregation of leaves of Passifora nitida Kunth (Passiforaceae). Acta Amaz. 2010, 40, 199-206.

32. Melo, F.R.; Mourão, P.A. An algal saulfated galactan has unusual dual effect on venous thrombosis due to activation of factor XII and inhibition of the coagulation proteases. Thromb. Haemostasis 2008, 99, 531-538.

33. De Azevedo, T.C.G.; Bezerra, M.E.B.; Santos, M.G.L.; Souza, L.A.; Marques, C.T.; Benevides, N.M.B.; Leite, E.L. Heparinoids algal and their anticoagulant, hemorrhagic activities and platelet aggregation. Biomed. Pharmacother. 2008, 63, 477-483.

34. Surin, W.R.; Barthwal, M.K.; Dikshit, M. Platelet collagen receptors, signaling and antagonism: Emerging approaches for the prevention of intravascular thrombosis. Thromb. Res. 2008, 122, 786-803.

35. Clemetson, K.J.; Clemetson, J.M. Collagen receptors as potential targets for novel anti-platelet agents. Curr. Pharm. Des. 2007, 13, 2673-2683.

36. Rivera, J.; Lozano, M.L.; Navarro-Núñez, L.; Vicente, V. Platelet receptors and signaling in the dynamics of thrombus formation. Haematologica 2009, 94, 700-711.

37. Suzuki-Inoue, K.; Fuller, G.L.; Garcia, A.; Eble, J.A.; Pohlmann, S.; Inoue, O.; Gartner, T.K.; Hughan, S.C.; Pearce, A.C.; Laing, G.D.; et al. A novel Syk-dependent mechanism of platelet activation by the C-type lectin receptor CLEC-2. Blood 2006, 107, 542-549.

38. Maita, N.; Nishio, K.; Nishimoto, E.; Matsui, T.; Shikamoto, Y.; Morita, T.; Sadler, J.E.; Mizuno, H. Crystal structure of von Willebrand factor A1 domain complexed with snake venom, bitiscetin: Insight into glycoprotein Ibalpha binding mechanism induced by snake venom proteins. J. Biol. Chem. 2003, 278, 37777-37781.

39. Chen, Z.M.; Wu, J.B.; Zhang, Y.; Yu, G.Y.; Lee, W.H.; Lu, Q.M.; Zhang, Y. Jerdonuxin, a novel snaclec (snake C-type lectin) with platelet aggregation activity from Trimeresurus jerdonii venom. Toxicon 2011, 57, 109-116.

40. Ortiz-Ramirez, F.A.; Cavalcanti, D.N.; Villaça, R.C.; de Paula, J.C.; Valentin, Y.Y.; Teixeira, V.L. Chemical variations in the diterpenes from the Brazilian brown alga Dictyota menstrualis (Dictyotaceae, Phaeophyta). Nat. Prod. Commun. 2008, 11, 1879-1884.

41. Fuly, A.L.; de Miranda, A.L.; Zingali, R.B.; Guimarães, J.A. Purification and characterization of a phospholipase $\mathrm{A}_{2}$ isoenzyme isolated from Lachesis muta snake venom. Biochem. Pharmacol. 2002, 63, 1589-1597.

Samples Availability: Available from the authors.

(C) 2011 by the authors; licensee MDPI, Basel, Switzerland. This article is an open access article distributed under the terms and conditions of the Creative Commons Attribution license (http://creativecommons.org/licenses/by/3.0/). 